\title{
Usage of English Communicative Skills in the Workplace Context
}

\author{
Bundit Anuyahong \\ English Department, College of General Education and Languages, Thai-Nichi Institute of Technology, Bangkok, Thailand \\ DOI: https://dx.doi.org/10.51244/IJRSI.2021.8408
}

\begin{abstract}
The purposes of this study were 1) to investigate usage of English communicative skills in the workplace context, and 2) to study additional suggestions from respondents. The research samples were 350 staff working in different fields and organizations in Bangkok derived through Simple Random Sampling technique. The instruments used for collecting the data were the rating-scale and open-ended questionnaire. Frequency, percentage, mean, standard deviation and content analysis were used for data analysis. The research findings presented that usage of English communicative skills in the workplace context was at the highest level. The highest usage communicative skill was Listening skills and the lowest one was Reading skills. The additional suggestions from the respondents highly concerned on a training for making or receiving business phone call, interpreting and translating documents in English, English workshop or seminar, and socializing formally with business partners.
\end{abstract}

Keywords: English in the Workplace Context, English Communicative Skills in the Workplace, Usage of Commumicative Skills in the Workplace

\section{INTRODUCTION}

$\mathrm{T}$ The use of English in today's world extends far beyond classrooms. It is spoken by more non-native speakers than native, and can be found anywhere from street corners to office buildings. In the past decades, research in Second Language Acquisition (SLA) has developed to better understand this real world communication, with emphasis placed on the importance of context, the language user, and interactions that take place (Firth, 2009). The workplace is one such context. English is now widely considered to be the de facto language of use in many industries. Investigation into workplace English has mostly been conducted in two areas of research, English for Specific Purposes (ESP) and Business English as a Lingua Franca (BELF). ESP is an older field with the goal of identifying the needs of a specific group to direct teaching to best fit their purposes and ESP has traditionally focused on language needs such as reading, or technical vocabulary. Whereas ESP could apply to any context, including the workplace, according to Kankaanranta \& Planken (2010) BELF pertains to the world of business, often internationally.

As a result of economic growth in Thailand in recent decades, many Thai companies expanded to compete regionally and internationally. This has led to an increase in associations, mergers and takeovers among these companies.
Furthermore, the global reach of multinational companies requires the use of a common language, such as English, for the purpose of communication (Wiriyachitra, 2011). In this way, it might be concluded that English has become even more important as a means of communication between native and non-native English speakers (Cotton et al. 2000).

\section{Research Purposes}

The purposes of this study were:

1) to investigate usage of English communicative skills in the workplace context in four aspects: Listening skills; Speaking skills; Reading skills and Writing skill; and

2) to study additional suggestions from respondents.

\section{RESEARCH METHODOLOGY}

This study focused on usage of English communicative skills in the workplace context in Bangkok which consists of population and samples as follows:

The population of this study was 1080 Thai staff from seven organizations in Bangkok.

The samples of this study were 350 Thai staff from seven organizations derived through Simple Random Sampling technique.

\section{Instrumentation}

The instruments used for gathering the data were the rating-scale and open-ended questionnaire based on usage of English communicative skills in the workplace context of Thai staff in Bangkok.

The first part (Part 1) of the questionnaire asked for the demographic information of the respondents: Gender, Work Experience, and Work sector. The second part (Part 2) concerned with usage of English communicative skills in the workplace context of Thai staff in Bangkok. The third part (Part 3) asked for opinions and suggestions of the respondents.

The five levels of usage of English communicative skills in the workplace context used in the questionnaire were ranked as "The highest level", "High level", "Moderate level", "Low level", and "The lowest level". Responses from the questionnaires were subsequently coded. The data of the 
respondents' coded responses were statistically calculated and analyzed.

\section{Data Analysis}

Both single item and whole questionnaire were analyzed by using rating scale. These rating scales were calculated to find out mean and standard deviation and then translated based on criteria developed by Best (1981) as follows:

$\begin{array}{ll}5 & \text { refers to The highest level } \\ 4 & \text { refers to High level } \\ 3 & \text { refers to Moderate level } \\ 2 & \text { refers to Low level } \\ 1 & \text { refers to The lowest level }\end{array}$

This, then, is calculated into mean scores as a following formulation.

$1.00 \leq \overline{\mathrm{X}}<1.50$ refers to the lowest level.

$1.51 \leq \overline{\mathrm{X}}<2.50$ refers to low level.

$2.51 \leq \overline{\mathrm{X}}<3.50$ refers to moderate level.

$3.51 \leq \overline{\mathrm{X}}<4.50$ refers to high level.

$4.51 \leq \overline{\mathrm{X}}<5.00$ refers to the highest level.

The statistics used for analyzing the data were frequency, percentage, mean, standard deviation, and content analysis.

\section{RESULTS}

Part 1: Results of the demographic data of the respondents

Table 1: Results of the Demographic Data of the Respondents

\begin{tabular}{|l|l|l|}
\hline $\begin{array}{l}\text { Demographic data of the } \\
\text { respondents }\end{array}$ & $n$ & Percentage \\
\hline 1. Gender \\
\hline 1.1) Male & 181 & 51.71 \\
\hline 1.2) Female & 169 & 48.29 \\
\hline Total & $\mathbf{3 5 0}$ & $\mathbf{1 0 0}$ \\
\hline 2. Work experience & \multicolumn{2}{|l|}{} \\
\hline 2.1) Less than 1 year & 25 & 7.14 \\
\hline 2.2) 1-5years & 89 & 25.43 \\
\hline 2.3) 6-10 years & 104 & 29.71 \\
\hline 2.4) 11-15 years & 67 & 19.14 \\
\hline 2.5) 16-20 years & 52 & 14.86 \\
\hline 2.6) More than 20 years & 13 & 3.72 \\
\hline Total & $\mathbf{3 5 0}$ & $\mathbf{1 0 0}$ \\
\hline 3. Work sector & & \\
\hline 4.1) Private sector & 112 & 32.00 \\
\hline 4.2) Government sector & 149 & 42.57 \\
\hline $\begin{array}{l}\text { 4.3) Semi-government } \\
\text { sector }\end{array}$ & 89 & 25.43 \\
\hline
\end{tabular}

\begin{tabular}{|l|l|l|}
\hline $\begin{array}{l}\text { Demographic data of the } \\
\text { respondents }\end{array}$ & $n$ & Percentage \\
\hline Total & 350 & 100 \\
\hline
\end{tabular}

Table 1 showed that percentages of respondents in genders ranged from $51.71 \%$ as male staff and $48.29 \%$ as female staff. For work experience, the percentages ranged from $7.14 \%$ for less than 1 year, followed by $25.43 \%$ for $1-5$ years, $29.71 \%$ for $6-10$ years, $19.14 \%$ for $11-15$ years, $14.86 \%$ for $16-20$ years, and $3.72 \%$ for more than 20 years. For work sector, the percentages ranged from $32.00 \%$ for Private sector, followed by $42.57 \%$ for Government sector, and $25.43 \%$ for Semi-government sector.

Part 2: Results of usage of English communicative skills in the workplace context

Table 2: Mean $(\overline{\mathrm{X}})$ and Standard Deviation (S.D.) of usage of English communicative skills in the workplace context in Overall

\begin{tabular}{|c|c|c|c|c|}
\hline No. & Aspects & $\overline{\mathrm{X}}$ & S.D. & Level \\
\hline 1. & Listening skills & 4.65 & 0.61 & Highest \\
\hline 2. & Speaking skills & 4.63 & 0.57 & Highest \\
\hline 3. & Reading skills & 4.50 & 0.61 & High \\
\hline 4. & Writing skills & 4.61 & 0.59 & Highest \\
\hline \multicolumn{2}{|r|}{ Total } & 4.60 & 0.58 & Highest \\
\hline
\end{tabular}

The above table indicated that usage of English communicative skills in the workplace context in overall was at the highest level $(\bar{X}=4.60)$. The highest rank at the highest level was Listening skills $(\overline{\mathrm{X}}=4.65)$, followed by Speaking skills, Writing skills and Reading skills $(\bar{X}=4.63, \bar{X}=4.61$ and $\bar{X}=4.50$ respectively).

Table 3: Mean $(\overline{\mathrm{X}})$ and Standard Deviation (S.D.) of usage of English communicative skills in the workplace context.in Listening skills

\begin{tabular}{|l|l|l|l|l|}
\hline No. & Components & $\overline{\mathrm{X}}$ & S.D. & Level \\
\hline 1. & $\begin{array}{l}\text { Listening to take notes of a } \\
\text { business meeting in English }\end{array}$ & 4.52 & 0.74 & Highest \\
\hline 2. & Listening to a speech in English & 4.83 & 0.69 & Highest \\
\hline 3. & $\begin{array}{l}\text { Listening to business } \\
\text { presentation in English }\end{array}$ & 4.74 & 0.51 & Highest \\
\hline 4. & $\begin{array}{l}\text { Listening to business report in } \\
\text { English }\end{array}$ & 4.54 & 0.64 & Highest \\
\hline 5. & $\begin{array}{l}\text { Listening to information from } \\
\text { more than one sources in } \\
\text { English }\end{array}$ & 4.61 & 0.47 & Highest \\
\hline & Total & $\mathbf{4 . 6 5}$ & $\mathbf{0 . 6 1}$ & Highest \\
\hline
\end{tabular}

The table presented that usage of English communicative skills in the workplace context in Listening skills was at the highest level $(\overline{\mathrm{X}}=4.65)$. The highest rank at the highest level was "Listening to a speech in a conference $\mathrm{n}$ in English" ( $\overline{\mathrm{X}}=4.83)$, followed by "Listening to business presentation in English" ( $\overline{\mathrm{X}}=4.74)$ whereas the lowest rank 
at the highest level was "Listening to take notes of a business meeting in English" ( $\overline{\mathrm{X}}=4.52)$.

Table 4: Mean $(\overline{\mathrm{X}})$ and Standard Deviation (S.D.) of usage of English communicative skills in the workplace context.in Speaking skills

\begin{tabular}{|l|l|l|l|l|}
\hline No. & Components & $\overline{\mathrm{X}}$ & S.D. & Level \\
\hline 1. & $\begin{array}{l}\text { Speaking formally in } \\
\text { English with business } \\
\text { partners }\end{array}$ & 4.63 & 0.41 & Highest \\
\hline 2. & $\begin{array}{l}\text { Giving formal speeches or } \\
\text { presentations in English at } \\
\text { international conference }\end{array}$ & 4.79 & 0.47 & Highest \\
\hline 3. & $\begin{array}{l}\text { Giving small speeches or } \\
\text { presentations in English at } \\
\text { work }\end{array}$ & 4.37 & 0.73 & High \\
\hline 4. & $\begin{array}{l}\text { Having discussion about } \\
\text { general topics and current } \\
\text { events in English }\end{array}$ & 4.56 & 0.64 & Highest \\
\hline 5. & $\begin{array}{l}\text { Negotiating with } \\
\text { customers/suppliers in } \\
\text { English }\end{array}$ & 4.82 & 0.59 & Highest \\
\hline & Total & $\mathbf{4 . 6 3}$ & $\mathbf{0 . 5 7}$ & Highest \\
\hline
\end{tabular}

The table demonstrated that usage of English communicative skills in the workplace context in Speaking skills was at the highest level $(\overline{\mathrm{X}}=4.63)$. The highest rank at the highest level was "Negotiating with customers/suppliers in English" ( $\overline{\mathrm{X}}=4.82)$, followed by "Giving formal speeches or presentations in English at international conference" $(\overline{\mathrm{X}}=$ 4.79) whereas the lowest rank at a high level was "Giving small speeches or presentations in English at work" $(\overline{\mathrm{X}}=$ 4.37).

Table 5: Mean ( $\overline{\mathrm{X}}$ ) and Standard Deviation (S.D.) of usage of English communicative skills in the workplace context.in Reading skills

\begin{tabular}{|l|l|l|l|l|}
\hline No. & Components & $\overline{\mathrm{X}}$ & S.D. & Level \\
\hline 1. & $\begin{array}{l}\text { Reading English articles } \\
\text { on the internet }\end{array}$ & 4.42 & 0.45 & High \\
\hline 2. & $\begin{array}{l}\text { Reading English } \\
\text { newspaper, magazines } \\
\text { and research papers }\end{array}$ & 4.37 & 0.62 & High \\
\hline 3. & $\begin{array}{l}\text { Reading emails from } \\
\text { business partners written } \\
\text { in English }\end{array}$ & 4.61 & 0.74 & Highest \\
\hline 4. & $\begin{array}{l}\text { Reading contracts from } \\
\text { business partners writing } \\
\text { in English }\end{array}$ & 4.53 & 0.69 & Highest \\
\hline 5. & $\begin{array}{l}\text { Reading business reports } \\
\text { written in English }\end{array}$ & 4.59 & 0.57 & Highest \\
\hline & Total & $\mathbf{4 . 5 0}$ & $\mathbf{0 . 6 1}$ & High \\
\hline
\end{tabular}

The table illustrated that usage of English communicative skills in the workplace context in Reading skills was at a high level $(\bar{X}=4.50)$. The highest rank at the highest level was "Reading emails from business partners written in English" ( $\overline{\mathrm{X}}=4.61)$, followed by "Reading business reports written in English" ( $\overline{\mathrm{X}}=4.61)$ whereas the lowest rank at a high level was "Reading English newspaper, magazines and research papers" $(\overline{\mathrm{X}}=4.37)$.

Table 6: Mean $(\overline{\mathrm{X}})$ and Standard Deviation (S.D.) of usage of English communicative skills in the workplace context.in Writing skills

\begin{tabular}{|l|l|l|l|l|}
\hline No. & Components & $\overline{\mathrm{X}}$ & S.D. & Level \\
\hline 1. & $\begin{array}{l}\text { Writing business } \\
\text { documents in English }\end{array}$ & 4.42 & 0.59 & High \\
\hline 2. & $\begin{array}{l}\text { Writing } \\
\text { email/business letter } \\
\text { in English }\end{array}$ & 4.65 & 0.63 & Highest \\
\hline 3. & $\begin{array}{l}\text { Writing notices, } \\
\text { agenda, and minutes } \\
\text { in English }\end{array}$ & 4.76 & 0.71 & Highest \\
\hline 4. & $\begin{array}{l}\text { Writing reports in } \\
\text { English }\end{array}$ & 4.69 & 0.45 & Highest \\
\hline 5. & $\begin{array}{l}\text { Writing document } \\
\text { contracts in English }\end{array}$ & 4.53 & 0.59 & Highest \\
\hline & Total & $\mathbf{4 . 6 1}$ & $\mathbf{0 . 5 9}$ & Highest \\
\hline
\end{tabular}

The table illustrated that usage of English communicative skills in the workplace context in Writing skills was at the highest level $(\overline{\mathrm{X}}=4.61)$. The highest rank at the highest level was "Writing notices, agenda, and minutes in English" ( $\overline{\mathrm{X}}=4.76)$, followed by "Writing reports in English" $(\overline{\mathrm{X}}=4.69)$ whereas the lowest rank at a high level was "Writing business documents in English" $(\overline{\mathrm{X}}=4.42)$.

Part 3: Opinions and Suggestions from the Respondents

The opinions and suggestions from the respondents were listed as follows:

1. Staff should be trained for making or receiving business phone call.

2. Interpreting and translating documents in English should be concerned.

3. Staff should be organized to participate in English workshop or seminar more than before.

4. Staff should be trained to socialize formally with business partners.

\section{CONCLUSION}

According to the findings, it was indicated that usage of English communicative skills in the workplace context in overall was at the highest level. The highest usage of communicative skills in the workplace context was listening skills whilst the lowest usage of communicative skills in the workplace was reading skills. The additional suggestions from the respondents highly concerned on a training for making or receiving business phone call, interpreting and translating documents in English, English workshop or seminar, and socializing formally with business partners. 


\section{DISCUSSIONS}

According to Gufey \& Loewy (2010), soft skills such as listening, writing, and speaking are most likely to determine hiring and career success. Listening, however, is especially the highest important in workplaces when comparing with other skills as because the employees spend a lot of time doing it. Although estimates vary, it is thought that most workers spend 30 to 45 percent of their communication time in listening. Moreover, the least usage of reading skills was relevant to the study of Mordaunt et al. (2017) who state that reading was seen as least challenging, more frequently used, but less desired for improvement.

Employers usually gain an advantage by hiring employees with high language proficiency. Thus, in the recruitment process, language proficiency is one of the criteria concerned (Hofstede and Hofstede, 2005), and various aspects of foreign language (i.e. grammar, phonology, lexis, syntax, pragmatics) are one of the factors emphasized for the trauma or success with foreign languages with the competency in communication, are correlated to a process of gauging overall proficiency (Dewaele et al., 2008).

\section{REFERENCES}

[1]. Best, J. (1981). Research in education (4th ed.). New Jersey: Prentice Hall.

[2]. Cotton, D., David, F. and Simon, K.. (2000). Market Leader. Spain: Mateu Cromo, S.A. Pinto. (Madrid).

[3]. Dewaele, J.M., Petrides, K.V. and Furnham, A. (2008). Effects of trait emotional intelligence and sociobiographical variables on communicative anxiety and foreign language anxiety among adult multilinguals: a review and empirical investigation. Language and Learning, 59, 911-960 (2008).

[4]. Firth, A. (2009). Doing not being a foreign language learner: English as a lingua franca in the workplace and (some) implications for SLA. International Review of Applied Linguistics, 47, 127-156.

[5]. Gufey, M. E. \& Loewy, D. (2010). Business Communication: Process and Product. USA: Cengage Learning.

[6]. Hofstede, G. and Hofstede, G. (2005). Cultures and Organizations: Software of the Mind. McGraw-Hill.

[7]. Kankaanranta, A., \& Planken, B. (2010). BELF competence as business knowledge of internationally operating business professionals. The Journal of Business Communication, 47(4), 380-407.

[8]. Malicka, A., Gilabert, R., \& Norris, J. M. (2017). From needs analysis to task design: insights from an English for specific purposes context. Language Teaching Research.

[9]. Witchaiyutphong, K. (2011). English Barriers for Thai Employees Working in an International Setting, A Study at Thomson Reuters Company in Thailand. Unpublished Master's research paper, Thammasat University. 